\title{
Article \\ Optical Spectral Tools for Diagnosing Water Media Quality: A Case Study on the Angara/Yenisey River System in the Siberian Region
}

\author{
Costas A. Varotsos ${ }^{1,2}$ D, Vladimir F. Krapivin ${ }^{3}$, Ferdenant A. Mkrtchyan ${ }^{3}$ and Yong Xue ${ }^{2,4, *(D)}$ \\ 1 Department of Environmental Physics and Meteorology, University of Athens, 15784 Athens, Greece; \\ covar@phys.uoa.gr \\ 2 School of Environment Science and Geoinformatics, China University of Mining and Technology, \\ Xuzhou 221116, China \\ 3 Kotelnikov Institute of Radioengineering and Electronics, Fryazino Branch, Russian Academy of Sciences, \\ Fryazino, 141190 Moscow, Russia; vkrapivin_36@mail.ru (V.F.K.); ferd47@mail.ru (F.A.M.) \\ 4 College of Science and Engineering, University of Derby, Derby DD22 3AW, UK \\ * Correspondence: yxue@cumt.edu.cn
}

Citation: Varotsos, C.A.; Krapivin, V.F.; Mkrtchyan, F.A.; Xue, Y. Optical Spectral Tools for Diagnosing Water Media Quality: A Case Study on the Angara/Yenisey River System in the Siberian Region. Land 2021, 10, 342. https://doi.org/10.3390/land10040342

Academic Editors: Julia Jones and Saurav Kumar

Received: 22 December 2020

Accepted: 17 March 2021

Published: 27 March 2021

Publisher's Note: MDPI stays neutra with regard to jurisdictional claims in published maps and institutional affiliations.

Copyright: (c) 2021 by the authors. Licensee MDPI, Basel, Switzerland. This article is an open access article distributed under the terms and conditions of the Creative Commons Attribution (CC BY) license (https:// creativecommons.org/licenses/by/ $4.0 /)$.

\begin{abstract}
This paper presents the results of spectral optical measurements of hydrochemical characteristics in the Angara/Yenisei river system (AYRS) extending from Lake Baikal to the estuary of the Yenisei River. For the first time, such large-scale observations were made as part of a joint American-Russian expedition in July and August of 1995, when concentrations of radionuclides, heavy metals, and oil hydrocarbons were assessed. The results of this study were obtained as part of the Russian hydrochemical expedition in July and August, 2019. For in situ measurements and sampling at 14 sampling sites, three optical spectral instruments and appropriate software were used, including big data processing algorithms and an AYRS simulation model. The results show that the water quality in AYRS has improved slightly due to the reasonably reduced anthropogenic industrial impact. Chemical concentrations in water have been found to vary along the Angara River depending on the location of the dams. The results of in situ measurements and modeling evaluations are given. To overcome the uncertainties in the data caused by the large monitoring area, it is recommended to use the combined AYRS simulation model and the universal 8-channel spectrophotometer installed on a fixed platform for continuous monitoring.
\end{abstract}

Keywords: optical spectrum; chemicals; water pollution; modelling; spectrophotometer; spectroellipsometer

\section{Introduction}

The Angara River is a major tributary of the Yenisei River. It flows rapidly north of Lake Baikal for about two-thirds of its $1779 \mathrm{~km}$, before turning west at its confluence with the Yenisei River, which flows north to the Kara Sea, draining an area of about 2.58 million $\mathrm{km}^{2}$ along a $4102 \mathrm{~km}$ journey. The Yenisei's flow rate in the Kara Sea fluctuates widely, averaging 19,800 $\mathrm{m}^{3} / \mathrm{s}$, and up to $130,000 \mathrm{~m}^{3} / \mathrm{s}$ during the spring run-off [1]. The share of the Angara-Yenisei river system (AYRS) in the total inflow of rivers into the Kara Sea varies from $22.1 \%$ to $26.4 \%$, which requires an assessment of the role of the Angara-Yenisei River system in Arctic water pollution [2-10].

The growing interest in Siberia's environmental problems is mainly due to the potential global consequences of Siberian rivers' pollution, given a variety of possible sources of pollution and their pathways of spread, including atmospheric and river transport. As the main tributary of the Yenisei River, the Angara River flowing into an industrial area has a negative cumulative effect on water quality and contributes to the negative changes of the Angara/Yenisei hydrological and hydrochemical system. The Angara River is the only run-off of Lake Baikal [4,11-15]. Very negative environmental effects on the Angara/Yenisei river system come from biogenic substances, including nitrogen 
and phosphate compounds [13]. Existing AYRS experimental water quality measurements reflect pollutant content mainly at local sites. Savichev and Matveenko [16] characterized the mineralization of the surface waters of the Angara River in the Boguchan reservoir zone as 20-40 mg/L. Sorokovikova [17] showed that many contaminants have an irregular distribution along the Yenisey. Concentrations of nitrogen, phosphorus, and organic compounds were found to increase, and their dynamics in space and time changed. Seasonal concentrations of mineral nitrogen, phosphorus, and sulfates were estimated in [18,19].

This article examines the pollution of the Angara/Yenisei River as a whole, using spectral optical monitoring tools. Optical measurements were obtained at a set of points and converted to concentrations and fluxes using the AYRS Hydrologic Simulation Model (AYRSSM). Due to the lack of access and lack of gaging, AYRSSM has been used in previous studies to link point samples to the river as a whole $[1,6,20,21]$. This provides an adequate description of the pollution of the Angara/Yenisei River flow, taking into account for the first time the role of the riverbeds' forms, improving the accuracy of the AYRS pollutant concentrations in the Kara Sea [20-22]. Many authors note that the coastal waters of the Kara Sea are characterized as moderately polluted, especially near the settlements of Amderma and Dikson [23]. AYRSSM provides consistent modeling results for these concentrations compared to their episodic measurements $[1,24]$. The difference between data from different authors can be greater than tens of percent; AYRSSM provides stability of modeling results, which is one percent.

The AYRS study was conducted by many authors. Savenko et al. [25] presented much evidence from previous hydrochemical water studies at the Yenisei estuary and in neighboring aquatories of the Kara Sea, focusing on the transformation processes of trace elements, phosphates, and organic matter. As mentioned above, the Angara River is one of the largest tributaries of the Yenisei River $(\approx 24$ percent of its runoff) and plays an important role in the pollution of the Yenisei River below the village of Strelka $[4,12,26,27]$. The Angara-Yenisei region is characterized by significant industrial activity, including aluminum production in Krasnoyarsk and Angarsk. Many studies on the water quality of the Angara/Yenisei River system have focused on monitoring and improving the evaluation process of highly reliable drinking water resources [28].

The main regulation of pollutant flows-discharged into the Kara Sea from the discharge of the Angara/Yenisei River system-is the five hydroelectric dams at Krasnoyarsk and the Sayano-Shushenskoe at Yenisei and Irkutsk, the Bratsk and Ust-Ilimsk at Angara. These dams are responsible for fluctuations in the flow regime and water balance of the Angara River [27]. The Angara river has an area of about $1.1106 \mathrm{~km}^{2}$, and the discharge at its outflow from Lake Baikal is estimated at $1855-1910 \mathrm{~m}^{3} / \mathrm{s}$, while towards the Yenisei River it is $4350-4530 \mathrm{~m}^{3}$ / s at the expense of its tributaries. A special feature of the Angara River is the uniformity of its runoff during the year in contrast to the Yenisei River, where the ratio of maximum to minimum runoff is equal to 80 in the Krasnoyarsk zone [19]. The Irkutsk reservoir receives water from Lake Baikal with annual fluctuations of $15.5 \%$. The consequent long-term dynamics of contaminant concentrations in water and sediments is determined by the location of the dams and the bottom relief [29-32].

The impact of industrial development in the area under consideration can be assessed taking into account all the cities with their dams, reservoirs and industrial structures. The main component of all pollutants discharged into the Angara River is sewage water $(85 \%)$, which is mainly distributed between the Bratsk Reservoir (45.2\%) and the Ust-Ilimsk Reservoir (39.8\%). Every year, the Angara River receives $0.66 \mathrm{~km}^{3} /$ year of sewage water, about $2 \%$ of which is treated at normal water quality levels [29].

A variety of estimates of AYRS pollution levels are made in different studies, as explained by the measurement in different years and seasons, as well as by the use of different instrumental tools. Most in situ surveys are carried out locally in existing water reservoirs and especially in the Angara source, the Irkutsk and Bratsk reservoirs [33]. Article [33] examines the impact of Bratsk-based economic entities on the environmental quality, taking into account the stable sources of non-ferrous metallurgy, the thermal power 
industry, and the pulp and paper industry. Significant research was carried out in [34] to assess changes in the hydrological regime of the Angara River before and after the construction of the fourth dam. River regulation at the four dams alters the seasonal water cycles of Lake Baikal and the Angara River; the long-term effects of river regulation on pollution have not been assessed. Nemirovskaya [35] found that the wider variability of hydrocarbon concentrations in surface waters was characteristic of the frontal zones of the Yenisei River mouth (4.8-69 $\mu \mathrm{g} / \mathrm{L})$. Herrault et al. [36] have demonstrated the effectiveness of optical remote sensing satellite observations in the operational assessment of AYRS water quality, including dissolved organic carbon.

The main idea of this study is to combine the use of optical sensors with data processing algorithms and modeling tools, both to develop a functional AYRS water quality data source and to evaluate the final pollutant flow to the Kara Sea at the Yenisei's estuary. Specifically, this paper presents key empirical results from field measurements and water sampling analysis that includes a specific list of chemicals. Concentrations of these pollutants are used to evaluate AYRS through the optical inverse task solution based on spectral optical observations. Because the bottom sediments are not analyzed in this study, the results of previous relevant studies are used [11,13,37-39]. It is therefore obvious that the present work stems from the need to extend previous studies in this field.

\section{Material and Methods}

The Yenisei River divides Western and Eastern Siberia. Figure 1 explains the geographical location of the Angara/Yenisei River system. As can be seen from this map, the availability of many sites along the AYRS for in situ measurements and sampling is low. Field measurements in AYRS outlets are constrained by limited access to sampling sites. Therefore, real knowledge of the AYRS status under the Angara mouth is often only possible with AYRSSM [6,21,40-42].

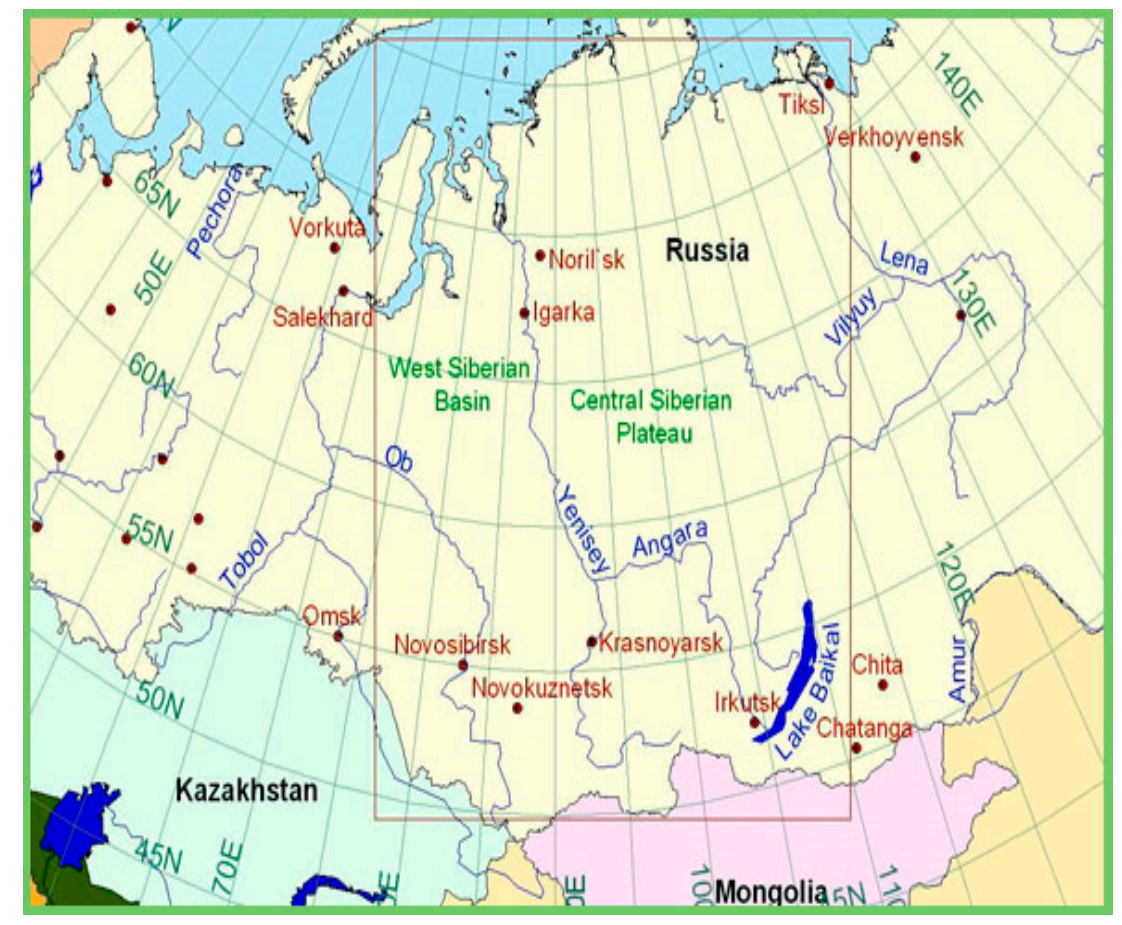

Figure 1. Location of the Angara/Yenisei River system in Central Siberia, Russia.

According to the current literature, the main sources of pollution of the Angara/Yenisei River are the main industrial centers of the cities of Krasnoyarsk, Irkutsk, Bratsk, Angarsk, Usolye-Sibirscoe, and Svirsk. The study of these sources and the subsequent conclusions about water quality have already been conducted by many authors $[12,13,28,43,44]$. Specif- 
ically, for the pollution of the Angara-Yenisei River, detailed information has been received from various missions in the past, such as the following:

(1) In the summer of 1995, the US-Russian environmental and hydrophysical campaign took place on the Angara and Yenisei rivers in Siberia. The following organizations participated in this mission: US Naval Research Laboratory (Washington, DC, USA), US Naval Academy (Annapolis, MD, USA), Global Technologies Inc. (Idaho Falls, ID, USA), Institute of Ecoinformatics of the Russian Academy of Natural Sciences (Moscow, Russia), Kotelnikov Institute of Radioengineering and Electronics of the Russian Academy of Sciences (Moscow, Russia), and Irkutsk State University (Irkutsk, Russia). The 44 main results of this mission have been published in [21,44].

(2) In the summer of 2019, a hydrochemical expedition was organized by the Institute of Ecoinformatic Problems, Russian Academy of Natural Sciences (Moscow, Russia). This study was based on spectral optical field measurements and water sampling. During this mission, three optical multi-spectral devices were used to measure water quality directly in situ and by water sampling. Water samples were delivered to the laboratory where optical spectral and chemical analyses were performed. Maps of in situ measurements and sample locations are shown in Figure 2.
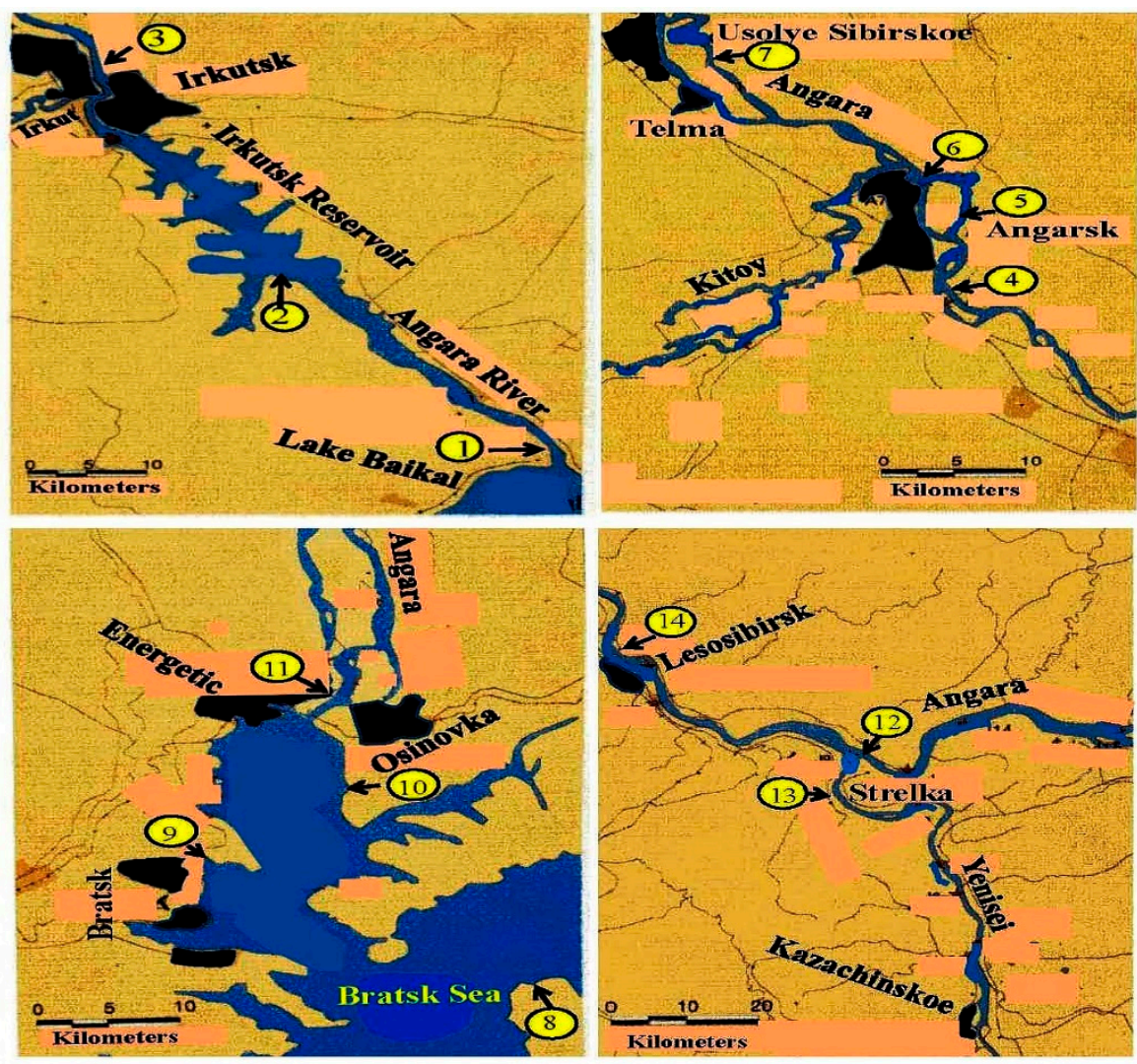

Figure 2. Fragments of the Angara/Yenisei River system and locations of spectral optical measurements and water sampling at a distance from Lake Baikal to Lesosibirsk.

In this study, three spectral optical devices and a cluster of computer components with suitable software were used, including data processing algorithms and AYRSSM. The characteristics of optical devices are shown in Table 1. For example, Figure 3 shows the main structure of the universal 8-channel spectrophotometer (US-8). 
Table 1. Characteristics of the spectral optical systems used in the study of the Angara/Yenisei River system.

\begin{tabular}{|c|c|}
\hline System & Characteristics \\
\hline Universal 8-channel spectrophotometer (US-8) & $\begin{array}{l}\text { The wavelength range is } 380-700 \mathrm{~nm} \text {. The } \\
\text { weight of the measuring device is } 6.2 \mathrm{~kg} \text {. } \\
\text { Spectrum recording time is } 0.8 \mathrm{~s} \text {. The US- } 8 \text { can } \\
\text { carry out in situ measurements (with and } \\
\text { without sampling). }\end{array}$ \\
\hline 35-channel spectrophotometer (SP-35) & $\begin{array}{l}\text { The wavelength range is } 300-800 \mathrm{~nm} \text {. The } \\
\text { weight of the device is } 3.9 \mathrm{~kg} \text {. Spectral image } \\
\text { recording time is } 0.5 \mathrm{~s} \text {. Spectral measurements } \\
\text { are performed when water samples are } \\
\text { delivered. }\end{array}$ \\
\hline $\begin{array}{l}\text { 128-channel spectroellipsometric system } \\
\text { (SS-128). }\end{array}$ & $\begin{array}{l}\text { The spectral range is } 380-780 \mathrm{~nm} \text {. The weight } \\
\text { of the measuring device is } 5.4 \mathrm{~kg} \text {. The } \\
\text { recording time of two spectral images is } 0.6 \mathrm{~s} \text {. } \\
\text { Water sampling is required. }\end{array}$ \\
\hline
\end{tabular}

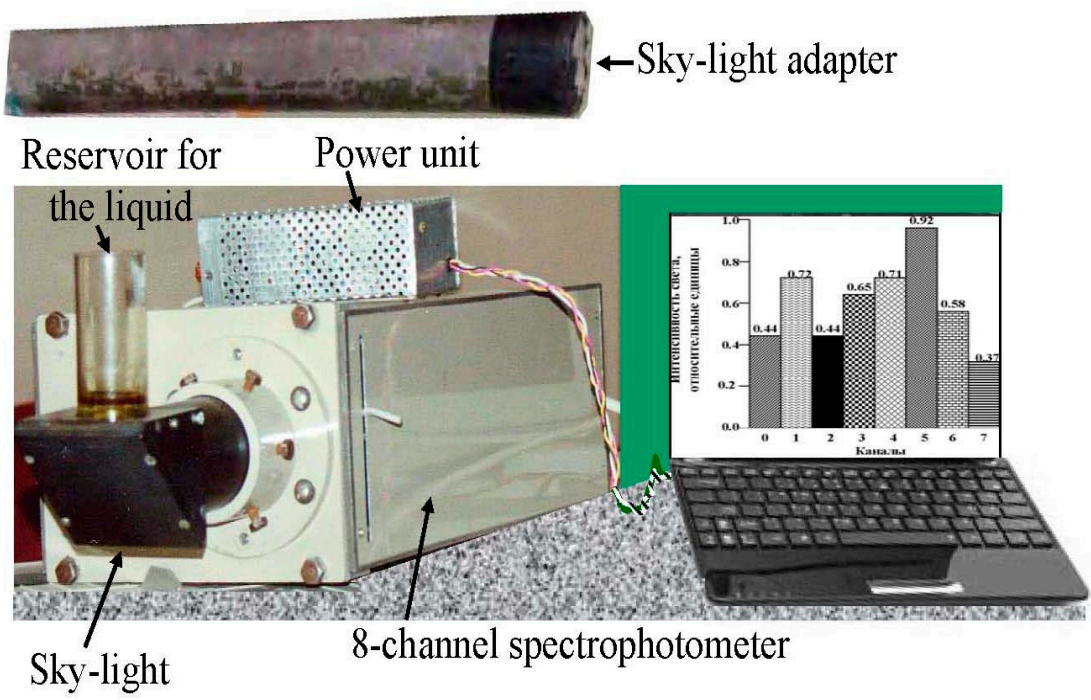

Figure 3. View of an adaptive 8-channel optical universal spectrophotometric decision-making system (US-8) used to study the characteristics of in situ spectral water and in the laboratory during water sampling.

Field measurements were performed using an 8-channel universal pre-training spectrophotometer (US-8) to identify spectral images from 380 to $700 \mathrm{~nm}$. US-8 software has algorithms for identifying and recognizing spectral images of the aquatic environment almost in real time. The main structure of the US- 8 is shown in Figure 3 . The US- 8 can use two light sources including sunlight or artificial light (a halogen bulb, a tiny xenon pulse lamp, etc.). The use of sunlight requires a calibration process performed automatically for a period of $1 \mathrm{~s}$. The in situ measurement procedure using the US- 8 consists of immersing the sky-light adapter ( $1 \mathrm{~m}$ long) in the water environment. The measurements were made by vessels in areas of interest and are shown in Figure 2. The incoming light reaches the adapter and the analog-to-digital converter provides the relaxation coefficient as an indicator of water quality. The 35-channel spectrophotometer was used to analyze a water sample under laboratory conditions. In this case, US-8 software was used. For more accurate spectral monitoring results, the 128-channel spectroellipsometer was used for spectral analysis of water sampling. In all cases, the average measurement time was $0.5-1.0 \mathrm{~s}$. The US-8 universality consists in its adaptation to the following three measurement modes: 
- direct measurement of the water relaxation coefficient by immersing part of the skyadapter into the water environment;

- formation of a spectral image of the water sample located in the special reservoir; and

- formation of a spectral image of the water surface when the sky-adapter is directed towards it.

Water quality is assessed through spectrophotometry/spectroellipsometry with inverse task solution or/and spectral images recognition. US- 8 and SP-35 provide an $S(\lambda)$ spectrum that reflects the relaxation coefficient depending on the wavelength $\lambda$. The recognition of such a spectrum is performed using cluster analysis and calculation of the distance between the spectra based on the spectral etalons database. The most effective algorithm for spectral image recognition is the transformation of spectral space into vector space when the optical spectrum is changed by the vector that reflects the shape of the spectrum. An example of a database item is given in Figure 4.

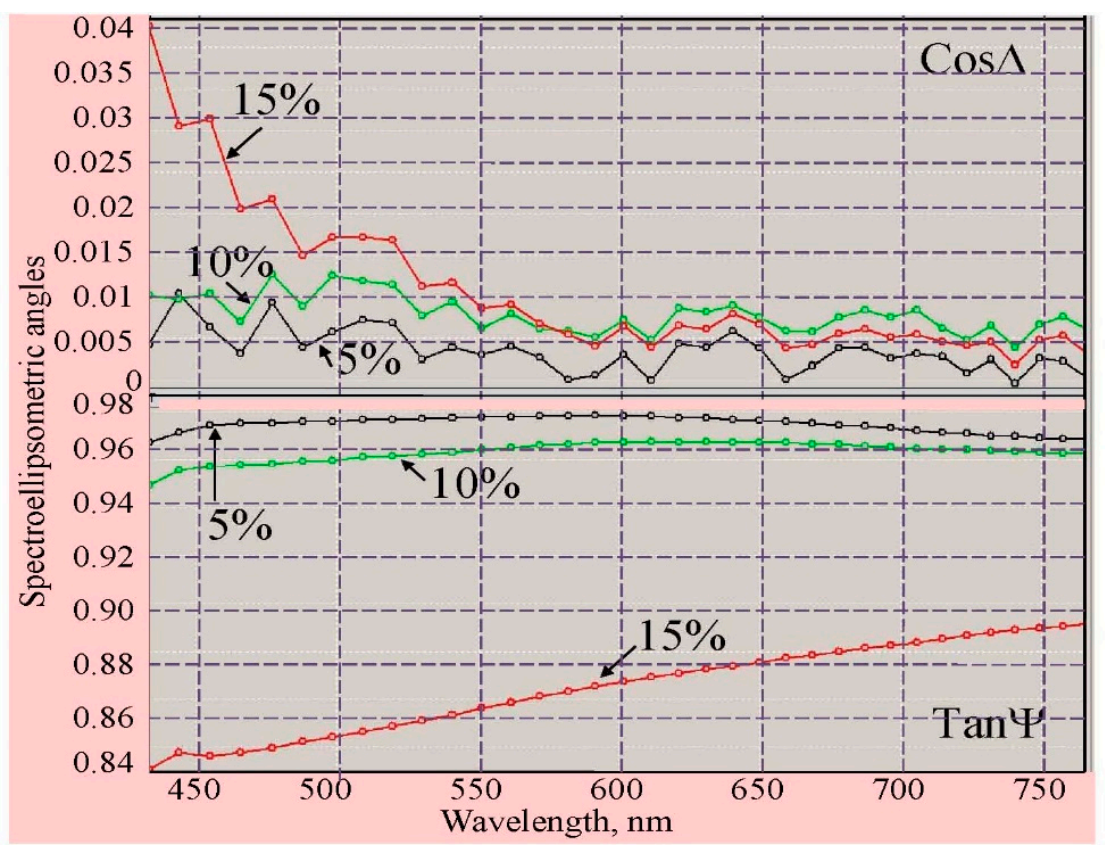

Figure 4. Spectral images of $\mathrm{ZnSO}_{4}$ dissolved in water at concentrations shown on the curves.

Spectrum processing and optical inverse task solution are applied for the universal case of spectroellipsometric measurements. According to the basic equation:

$$
\rho=r_{p} / r_{s}=\operatorname{Tan} \Psi \exp (i \Delta),
$$

where $r_{p}$ and $r_{s}$ are complex amplitude reflection coefficients. SS-128 provides spectra for polarizations $p$ and $s$ for the water sample $\eta$ :

- $S_{\Psi}(\lambda, \eta)$-spectral distribution of the tangent of the spectroellipsometric angle $\Psi$.

- $S_{\Delta}(\lambda, \eta)$-spectral distribution of the cosine of the spectroellipsometric angle $\Delta$.

The transformation of the optical spectral space into the vector space is achieved by direct evaluation of the specific characteristics of the spectrum. In this case, the spectra $S_{\Psi}(\lambda, \eta)$ and $S_{\Delta}(\lambda, \eta)$ are converted into two vectors: $\Xi_{\Psi}(\eta)=\left(C_{1 \Psi}, \ldots, C_{n \Psi}\right)$ and $\Xi_{\Delta}(\eta)=\left(C_{1 \Delta}, \ldots\right.$, $\left.C_{n \Delta}\right)$, where the values $C_{j \Psi}\left(C_{j \Delta}\right)$ reflect the physical parameters of the spectra:

- $C_{1 \Psi}\left(C_{1 \Delta}\right)$ is an area below the spectral curve.

- $\quad C_{2 \Psi}\left(C_{2 \Delta}\right)$ and $C_{3 \Psi}\left(C_{3 \Delta}\right)$ are the maximum and minimum coordinates of the spectral curves, respectively.

- $C_{4 \Psi}\left(C_{4 \Delta}\right)$ is the maximum distance between maximum and minimum coordinates. 
- $C_{5 \Psi}\left(C_{5 \Delta}\right)$ and $C_{6 \Psi}\left(C_{6 \Delta}\right)$ are the maximum values of the first and second derivatives of the spectral curve, respectively.

- $C_{7 \Psi}\left(C_{7 \Delta}\right)$ is the number of maximum spectral curves.

- $C_{8 \Psi}\left(C_{8 \Delta}\right)$ and $C_{9 \Psi}\left(C_{9 \Delta}\right)$ are the values of the spectrum coordinates at selected wavelengths $\lambda^{*}$ and $\lambda^{* *}$.

- $\quad C_{10 \Psi}\left(C_{10 \Delta}\right)$ is the relationship between the wavelength range evaluated for the maximum and minimum coordinates of the spectral curve.

Spectral recognition of the unknown spectra $S_{\Psi}(\lambda, x)$ and $S_{\Delta}(\lambda, x)$ is carried out by achieving a minimum value:

$$
\begin{gathered}
\left.\delta=\min _{s} \rho\left|\Xi_{\Delta}^{s}-\Xi_{\Delta}(x)\right|+\left|\Xi_{\Psi}^{s}-\Xi_{\Psi}(x)\right|\right\}= \\
\frac{1}{4 n} \min _{i}\left[\sum_{j=1}^{n}\left|X_{j \Delta}-C_{j \Delta}^{i}\right|+\sqrt{\sum_{j=1}^{n}\left(X_{j \Delta}-C_{j \Delta}^{i}\right)^{2}}\right]+ \\
\frac{1}{4 n} \min _{i}\left[\sum_{j=1}^{n}\left|X_{j \Psi}-C_{j \Psi}\right|+\sqrt{\sum_{j=1}^{n}\left(X_{j \Psi}-C_{j \Psi}\right)}\right]
\end{gathered}
$$

Another approach assumes that spectrum formation is linearly dependent on fluctuations in the concentration of contaminants. In this case, the solution of the optical inverse task is solved by the following system of algebraic equations:

$$
\left\{\begin{array}{c}
a_{11} x_{1}+\ldots+a_{1 m} x_{m}=S\left(\lambda_{1}, X\right) \\
\ldots \ldots \ldots \ldots \ldots \ldots \ldots \ldots \ldots \\
a_{k 1} x_{1}+\ldots+a_{k m} x_{m}=S\left(\lambda_{k}, X\right)
\end{array}\right.
$$

where $x_{j}(j=1, \ldots, m)$ is the concentration of the $j$ th contaminant in the water environment. The coefficients $a_{i j}$ are evaluated during the training procedure considering the facts of the over-defined $(m>k)$ or unspecified $(m<k)$ system [45].

The AYRSSM block diagram is shown in Figure 5, where its blocks are selected from the model functions. A description of the AYRSSM blocks is given in Table 2. The operational capabilities of the AYRSSM are more general than those required when considering the AYRS water quality assessment.

In addition, it is important to estimate the concentrations of chemicals in the water of the Yenisei estuary. These evaluations were performed using the AYRSSM described in detail by Krapivin et al. [21] and Krapivin and Varotsos [42,44]. The AYRSSM was improved by further examination of the AYRS structure, including four dams located along the Angara River and the bottom profile [38]. The AYRS watershed has an area $\Omega$ separated from the uniform geographic grids $\Omega_{k}(k=1, \ldots, N)$ located along the AYRS and other adjacent areas $\Omega_{i j}$ as sources of pollutant fluxes to AYRS. Cells $\Omega_{k}$ are located along the AYRS starting with $\Omega_{1}$ at the source of the Angara River to $\Omega_{N}$ at the mouth of the Yenisei River. Balance equations are used to parameterize the dynamics of water quality and pollutant concentration $[21,22,26,45]$.

The AYRSSM versions were calibrated as follows:

- $\quad$ monitoring of water quality in the Nuok Ngot Lagoon (South Vietnam) [41,42].

- study of heavy metal radionuclear pollutants in the AYRS and the Arctic Basin $[9,20,21,44]$; and

- monitoring of water quality in Lake Sevan (Armenia) [40].

The AYRSSM calibration procedure in this study is mainly based on the estimation of model sensitivity and the stability of the modeling results with variations in the number and location of sampling sites shown in Figure 2. Shifting and subtracting $25 \%$ of the sampling sites give the deviation of modeling results not more than $3 \%$. 


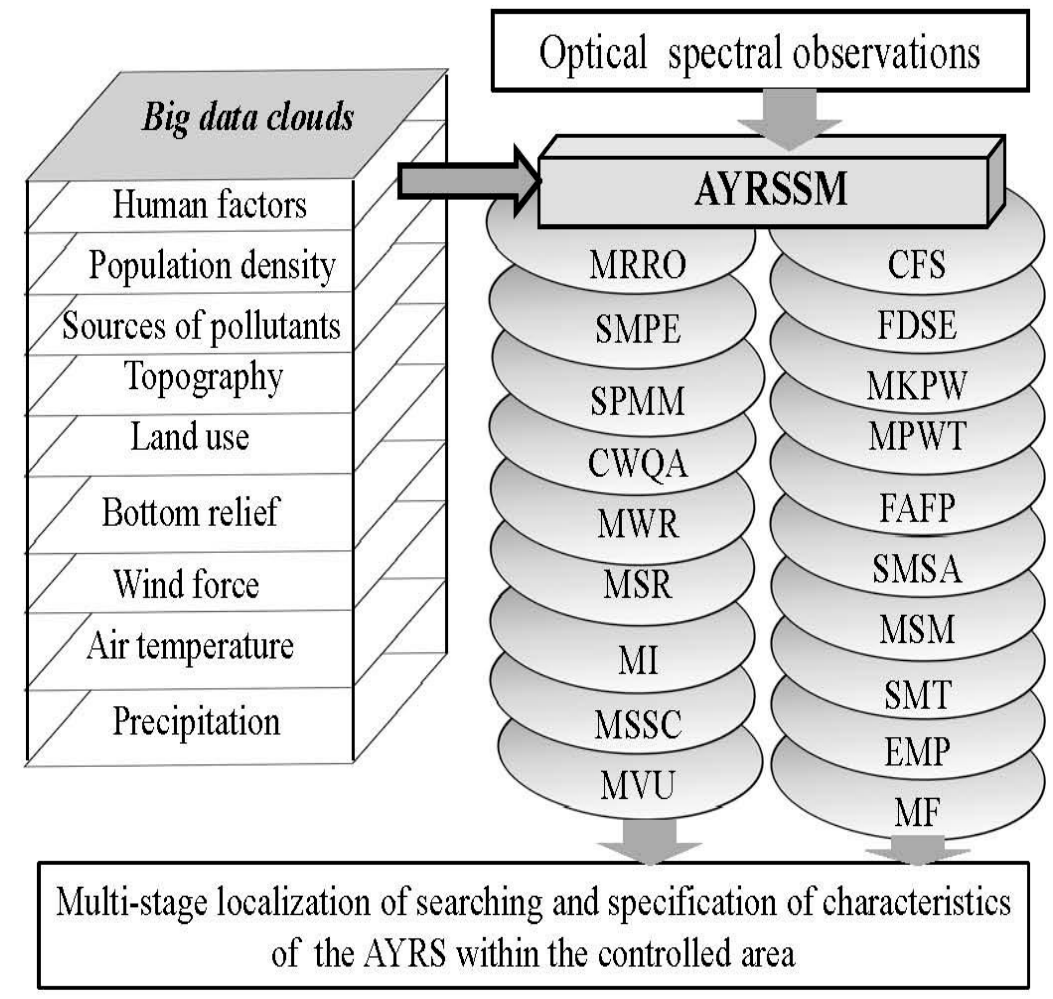

Figure 5. Structure of the AYRSSM. The description of the main blocks is given in Table 2.

Table 2. List of main blocks of AYRSSM.

\begin{tabular}{cl}
\hline Block & \multicolumn{1}{c}{ Description of the Block } \\
\hline MRRO & Model of the river run-off. \\
\hline SPMM & Simulation procedures for modeling the water masses' motion. \\
\hline SMPE & Set of models to parameterize the evaporation process. \\
\hline CWQA & Criteria for water quality assessment. \\
\hline MWR & Model of water regime in a water body. \\
\hline MSR & Model of spreading the river run-off across the river-bed. \\
\hline MI & Model of infiltration. \\
\hline MSSC & Model of the sink, taking into account the effect of vegetation and soil cover. \\
\hline MF & $\begin{array}{l}\text { Model of vertical uplifting of ground water during evaporation, feeding, and } \\
\text { exfiltration. }\end{array}$ \\
\hline EMP & Model of filtration. \\
\hline SMT & An empirical model of precipitation. \\
\hline MSM & Model of snow melting and evaporation from the snow surface. \\
\hline SMSA & A simulation model of sedimentation and biological assimilation of pollutants. \\
\hline FAFP & The formation of anthropogenic fluxes of pollutants. \\
\hline MPWT & Model of the process of the water temperature formation. \\
\hline MKPW & Model of kinetics of chemical pollution of water. \\
\hline FDSE & Formation of database of spectral etalons. \\
\hline CFS & Choice and formation of scenario for the simulation experiment. \\
\hline
\end{tabular}


The AYRSSM verification process involves the comparison of modeling results with in situ measurements. The range of modeling results at sampling sites (Figure 2) was 2.2\% to $3.4 \%$.

\section{Results and Discussion}

Figure 2 illustrates the sites for optical spectral measurements and water sampling. Table 1 shows optical decision-making systems used for in situ spectral measurements and analyses of water samples in laboratory conditions.

The combined process of water quality monitoring, algorithms, and AYRSSM allow the results to characterize the spatial distribution of contaminants along the Angara River and the Yenisei River after its intersection with Angara starting from the Strelka Village. The content of radionuclides in the river bottom sediments and their transport to the Kara Sea was studied earlier [21,45-47]. The analysis of the existing data on the radioactive pollution of Angara and Yenisei waters shows that continuous self-removal of radionuclides is observed. For example, the self-removal of ${ }^{137} \mathrm{C}$ is estimated at 0.191 /year, which corresponds to a half-purification time of 3.6 years for a $600 \mathrm{~km}$ section of the Angara/Yenisei riverbed $[43,46]$. Therefore, radioactive pollutants are not taken into account in this study.

The original source of pollution in Angara is Lake Baikal, whose water is affected by industrial activities located on the shores of the lake, according to Russian Federal Law defining the protection zone of the lake [47-50]. Industrial systems and cities along the Angara River add pollutants to the water. Downstream of the tributary junction, the water quality of Yenisei and Angara is determined by the average water properties. Further quantitative assessment of the pollutant budget in the Angara/Yenisei river system is assessed using a mass balance model [2,51]. The results of optical monitoring and model calculations are given in Tables 3-6 and Figures 6 and 7.

Table 3. Concentration of heavy metals $(\mu \mathrm{g} / \mathrm{L})$ in the water samples of the Angara River evaluated on the basis of the US-8 data.

\begin{tabular}{cccccccc}
\hline In-Situ Water Sampling & $\mathbf{A s}$ & $\mathbf{C d}$ & $\mathbf{C r}$ & $\mathbf{C u}$ & $\mathbf{N i}$ & $\mathbf{P b}$ & $\mathbf{Z n}$ \\
\hline $20 \mathrm{~km}$ of Angara from Baikal & 3.15 & 0.21 & 0.09 & 1.21 & 10.2 & 0.36 & 10.5 \\
\hline $30 \mathrm{~km}$ upstream from Irkutsk & 3.42 & 0.22 & 0.11 & 1.24 & 10.4 & 0.41 & 10.6 \\
\hline Angarsk (Angara) & 8.3 & 0.36 & 0.23 & 1.43 & 13.3 & 1.07 & 11.2 \\
\hline $\begin{array}{c}\text { Bratsk (Angara) } \\
\text { Bratsk, 0.5 km above the dam (15 }\end{array}$ & 11.2 & 1.15 & 0.32 & 2.48 & 15.4 & 1.09 & 13.6 \\
\hline $\begin{array}{c}\text { July 2019) } \\
\text { Bratsk, 0.5 km below the dam (15 }\end{array}$ & 10.7 & 1.13 & 0.27 & 2.39 & 11.2 & 0.98 & 13.2 \\
\hline $\begin{array}{c}\text { July 2019) } \\
\text { Bratsk, 0.5 km above the dam } \\
\quad \text { (August 15, 2019) }\end{array}$ & 8.21 & 0.97 & 0.34 & 1.87 & 14.8 & 0.84 & 12.7 \\
\hline $\begin{array}{c}\text { Bratsk, 0.5 km below the dam } \\
\text { (August 15, 2019) }\end{array}$ & 9.16 & 1.14 & 0.41 & 2.25 & 15.3 & 1.13 & 14.2 \\
\hline Kazachinskoe (Yenisey) & 10.4 & 1.17 & 0.19 & 1.54 & 15.3 & 1.13 & 13.7 \\
\hline Strelka (Angara flows into Yenisei) & 7.6 & 1.32 & 0.24 & 1.67 & 16.9 & 1.19 & 12.2 \\
\hline
\end{tabular}


Table 4. Average hydrochemical parameters of the Angara River evaluated during the 2019 expedition.

\begin{tabular}{|c|c|c|c|c|c|c|c|c|c|c|c|}
\hline \multirow[t]{2}{*}{ Site } & \multirow{2}{*}{$\begin{array}{l}\text { Distance from } \\
\text { Lake Baikal, km }\end{array}$} & \multicolumn{5}{|c|}{$\begin{array}{l}\text { Selected Trace and Toxic Heavy Metals, } \\
\mu \mathrm{g} / \mathrm{L}\end{array}$} & \multirow{2}{*}{$\begin{array}{l}\mathrm{PO}_{4}^{-3} \\
\mathrm{mg} / \mathrm{L}\end{array}$} & \multirow{2}{*}{$\begin{array}{r}\mathrm{NO}_{3}^{-} \\
+\mathrm{NO}_{2}^{-} \\
\mathrm{mg} / \mathrm{L}\end{array}$} & \multirow{2}{*}{$\begin{array}{l}\mathrm{NH}_{4}^{-} \\
\mathrm{mg} / \mathrm{L}\end{array}$} & \multirow{2}{*}{$\begin{array}{r}\mathrm{HCO}_{3}^{-} \\
\mathrm{mg} / \mathrm{L}\end{array}$} & \multirow{2}{*}{$\begin{array}{l}\mathrm{SO}_{4}^{2-} \\
\mathrm{mg} / \mathrm{L}\end{array}$} \\
\hline & & $\mathrm{Cd}$ & $\mathrm{Fe}$ & $\mathbf{N i}$ & $\mathrm{Pb}$ & As & & & & & \\
\hline 1 & 27 & 0.22 & 76.3 & 10.4 & 0.34 & 3.52 & 0.009 & 0.017 & 0.002 & 58.9 & 4.75 \\
\hline 2 & 68 & 0.22 & 84.4 & 10.6 & 0.34 & 5.91 & 0.011 & 0.019 & 0.013 & 64.2 & 5.44 \\
\hline 3 & 109 & 0.33 & 84.8 & 10.9 & 0.67 & 4.34 & 0.012 & 0.021 & 0.011 & 62.7 & 4.51 \\
\hline 4 & 123 & 0.44 & 84.5 & 11.1 & 0.73 & 6.28 & 0.034 & 0.017 & 0.018 & 65.8 & 5.89 \\
\hline 5 & 142 & 0.69 & 87.6 & 11.8 & 0.66 & 3.46 & 0.026 & 0.039 & 0.019 & 65.9 & 5.11 \\
\hline 6 & 157 & 0.78 & 93.2 & 11.4 & 0.46 & 2.75 & 0.021 & 0.081 & 0.016 & 64.1 & 4.72 \\
\hline 7 & 178 & 1.01 & 98.2 & 13.1 & 0.29 & 5.92 & 0.023 & 0.074 & 0.021 & 68.2 & 5.44 \\
\hline 8 & 547 & 1.14 & 95.3 & 12.4 & 0.73 & 7.12 & 0.059 & 0.067 & 0.033 & 63.6 & 5.98 \\
\hline 9 & 561 & 1.17 & 100.5 & 12.4 & 0.69 & 6.33 & 0.128 & 0.052 & 0.029 & 65.3 & 6.32 \\
\hline 10 & 643 & 0.95 & 114.4 & 13.3 & 0.59 & 7.34 & 0.112 & 0.067 & 0.035 & 68.4 & 6.13 \\
\hline 11 & 670 & 0.97 & 124.1 & 14.2 & 0.82 & 8.13 & 0.193 & 0.055 & 0.032 & 67.3 & 5.56 \\
\hline 12 & 1665 & 1.21 & 120.3 & 16.1 & 0.67 & 7.92 & 0.178 & 0.076 & 0.019 & 71.7 & 6.18 \\
\hline 13 & 1779 & 1.16 & 115.4 & 16.1 & 0.79 & 7.58 & 0.153 & 0.082 & 0.008 & 72.8 & 4.78 \\
\hline 14 & 1888 & 1.18 & 116.7 & 16.3 & 0.92 & 7.66 & 0.195 & 0.089 & 0.003 & 73.4 & 5.31 \\
\hline
\end{tabular}

Table 5. Comparison of concentrations of heavy metals and oil hydrocarbons in the Angara/Yenisei River system carried out in 1995 and 2019.

\begin{tabular}{|c|c|c|c|c|}
\hline \multirow[b]{2}{*}{ Site } & \multicolumn{2}{|c|}{1995} & \multicolumn{2}{|c|}{2019} \\
\hline & $\begin{array}{l}\text { Heavy Metals, } \\
\mu \mathrm{g} / \mathrm{L}\end{array}$ & $\begin{array}{l}\text { Oil Hydrocarbons, } \\
\text { mg/L }\end{array}$ & $\begin{array}{l}\text { Heavy Metals, } \\
\mu \mathrm{g} / \mathrm{L}\end{array}$ & $\begin{array}{c}\text { Oil Hydrocarbons, } \\
\text { mg/L }\end{array}$ \\
\hline (1) Angara source & 7.5 & 0.016 & 7.3 & 0.023 \\
\hline (2) Irkutsk, reservoir origin & 8.9 & 0.019 & 7.7 & 0.034 \\
\hline (3) Irkutsk, below dam & 8.7 & 0.021 & 7.6 & 0.045 \\
\hline (4) Above the Angarsk & 10.3 & 0.041 & 9.6 & 0.062 \\
\hline (5) Angarsk City zone & 11.5 & 0.054 & 9.9 & 0.067 \\
\hline (6) Below the Angarsk & 11.8 & 0.057 & 10.3 & 0.072 \\
\hline (7) Usolye Sibirskoe & 13.7 & 0.077 & 11.4 & 0.083 \\
\hline (8) Bratsk Sea & 12.6 & 0.084 & 11.6 & 0.088 \\
\hline (9) Bratsk City zone & 12.8 & 0.089 & 11.8 & 0.094 \\
\hline (10) Osinovka & 11.5 & 0.114 & 10.9 & 0.092 \\
\hline (11) Below energetic & 10.9 & 0.091 & 10.7 & 0.099 \\
\hline (12) Angara, Strelka & 12.4 & 0.182 & 11.6 & 0.176 \\
\hline (13) Yenisei, Strelka & 13.6 & 0.099 & 12.7 & 0.112 \\
\hline $\begin{array}{l}\text { (14) Angara/Yenisey, below } \\
\text { Strelka junction }\end{array}$ & 13.7 & 0.095 & 12.5 & 0.064 \\
\hline
\end{tabular}


Table 6. Model evaluation of the hydrochemical characteristics of water delivered from the Yenisei River to the Kara Sea.

\begin{tabular}{|c|c|c|c|c|c|c|c|}
\hline $\begin{array}{l}\text { Distance } \\
\text { from the } \\
\text { Angara } \\
\text { Junction } \\
\text { (Strelka) to } \\
\text { Kara Sea, } \\
\text { km }\end{array}$ & $\begin{array}{c}\text { Heavy } \\
\text { Metals, } \mu \mathrm{g} / \mathrm{L}\end{array}$ & $\mathrm{PO}_{4}^{-3}, \mathrm{mg} / \mathrm{L}$ & $\begin{array}{c}\mathrm{NO}_{3}^{-}+\mathrm{NO}_{2}^{-} \\
\mathrm{mg} / \mathrm{L}\end{array}$ & $\begin{array}{l}\text { Oil Hydro- } \\
\text { carbons, } \\
\text { mg/L }\end{array}$ & $\begin{array}{l}\mathrm{HCO}_{3}^{-} \\
\mathrm{mg} / \mathrm{L}\end{array}$ & $\begin{array}{l}\text { Mineralization, } \\
\mathrm{mg} / \mathrm{L}\end{array}$ & $\begin{array}{l}\mathrm{SO}_{4}^{2-} \\
\mathrm{mg} / \mathrm{L}\end{array}$ \\
\hline Strelka, 0 & 12.7 & 0.153 & 0.082 & 0.112 & 72.8 & 87.5 & 4.78 \\
\hline $\begin{array}{l}\text { Lesosibirsk, } \\
45\end{array}$ & 12.1 & 0.188 & 0.089 & 0.083 & 72.9 & 89.3 & 5.22 \\
\hline $\begin{array}{l}\text { Novoselovo, } \\
543 \\
\end{array}$ & 9.2 & 0.176 & 0.067 & 0.098 & 68.7 & 75.4 & 6.21 \\
\hline Igarka, 1161 & 7.7 & 0.088 & 0.034 & 0.066 & 64.5 & 62.1 & 6.33 \\
\hline $\begin{array}{l}\text { Dudinka, } \\
1405\end{array}$ & 6.9 & 0.063 & 0.012 & 0.045 & 57.3 & 54.8 & 5.25 \\
\hline Karaul, 1837 & 5.7 & 0.013 & 0.0052 & 0.043 & 45.1 & 41.6 & 4.92 \\
\hline $\begin{array}{c}\text { Dickson, } \\
2338\end{array}$ & 4.4 & 0.0015 & 0.0019 & 0.039 & 35.4 & 39.7 & 4.44 \\
\hline
\end{tabular}

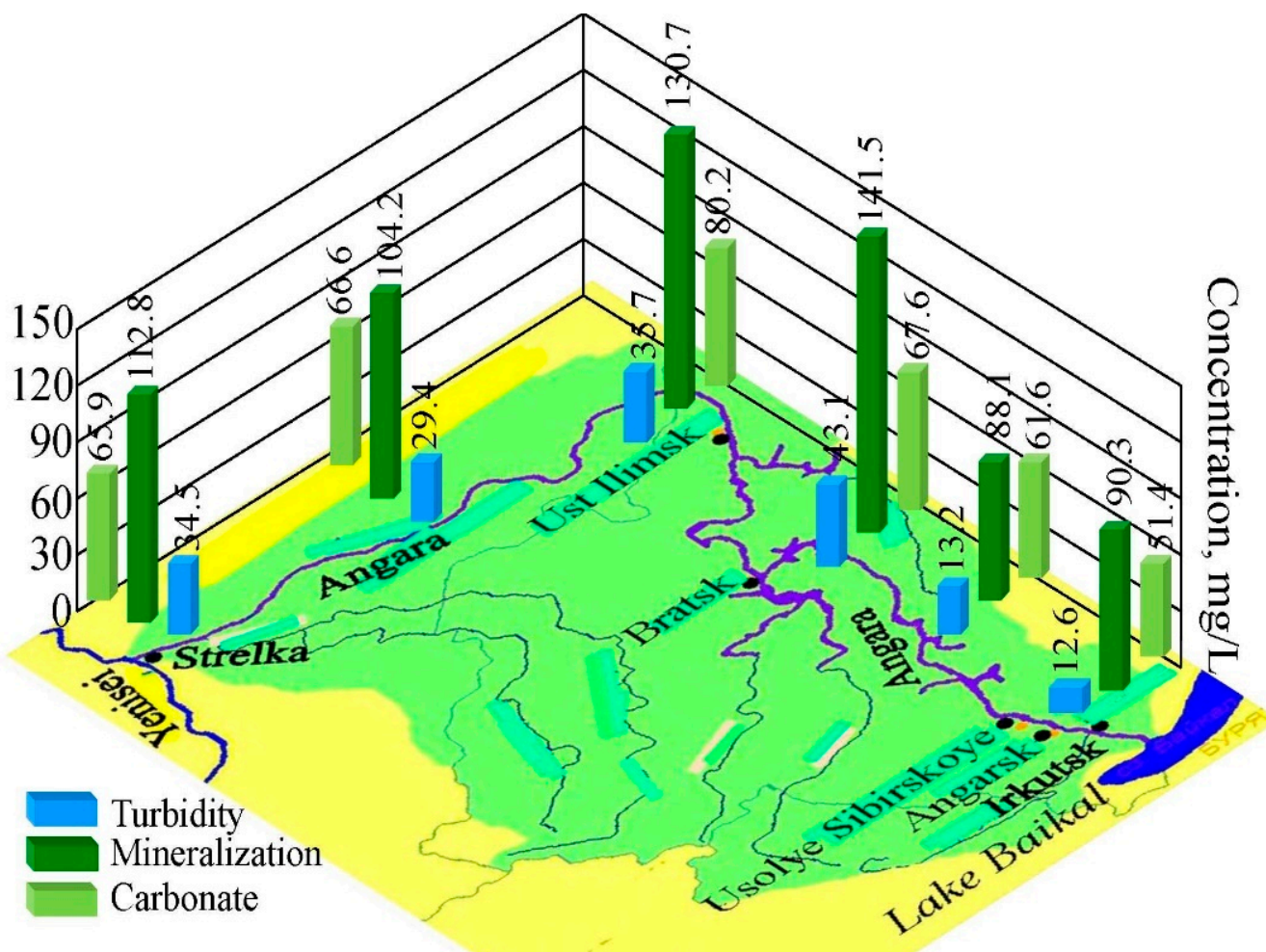

Figure 6. Distribution of water quality of the Angara River depending on the distance from Lake Baikal. 


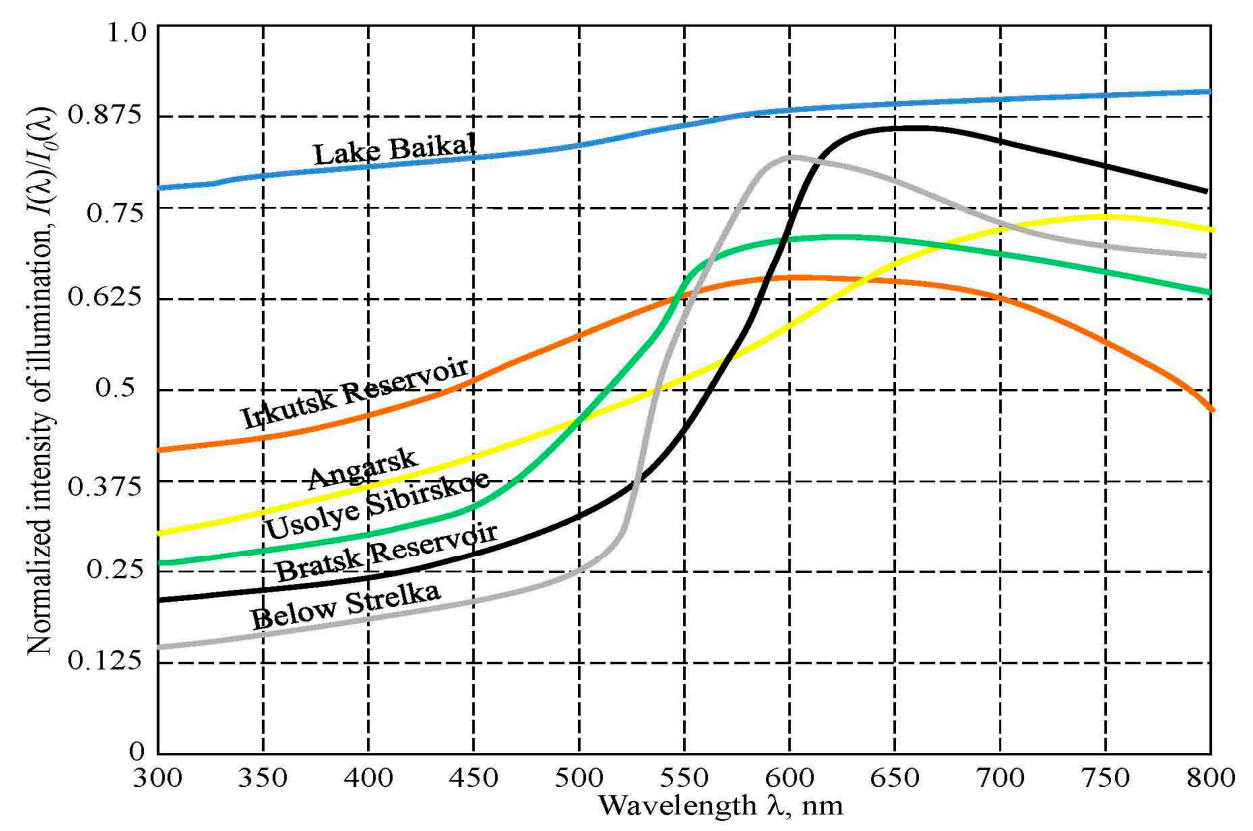

Figure 7. Optical spectral images of selected zones in the Angara/Yenisei River system.

The Angara River, the main subject of this study, has its source in the northern Lake Baikal and flows at the junction with the Yenisei River below the village of Strelka. The current of the Angara River is characterized as fast, with the existence of many jumps and rifts. These peculiarities play a significant role in the distribution of contaminants in the Angara waters $[1,4,18,25,48]$.

Almost all heavy metals are irregularly distributed in the Angara and Yenisei Rivers. This appears to be the result of the high velocity, turbulent flow, and coarse (gravel or cobble) bed of the rivers, including bedforms where heavy metals accumulate and are episodically remobilized. In portions of these rivers upstream of dams, the deposition of heavy metals on the river bed can result in reduced concentrations of metals in the water $[9,26,44]$. Indeed, the Bratsk, Irkutsk, and Ust-Ikimsk reservoirs manage fluctuations in the water level of the Angara River and thus provide the links between the content of the chemicals. According to Vyruchalkina [27], water discharges from the Angara River area near reservoirs and dams increased from a minimum in April to a maximum in September. As shown in Tables 2 and 3, heavy metals such as As, Ni, Fe, and $\mathrm{Zn}$ have high fluctuations in their concentrations depending on the distance from the Angara mouth. This result can be explained by their irregular concentrations in local waste waters, as defined by the types of industrial and socio-economic production.

An analysis of the monitoring results presented in Table 4 shows the reduction of the Angara pollution level almost all the way from Lake Baikal to the junction with the Yenisei River as part of the comparative expedition of Strelka Village in 1995 [44]. This result is explained by the reduction of industrial activity and the use of new technologies in the commercial sector.

In practice, measurements of concentrations of different chemical elements at sampling sites 1-14 indicate that the Angara River has a low level of mineralization and can be transferred to the hydrocarbon's category. A special role in shaping the water quality is played by the reservoirs located along the Angara River with their narrow spots and the widening of the lake-type, which significantly affect the process of turbulence and sedimentation. Mazaeva et al. [39] studied the dynamics of coastal processes with a digital relief model and showed that friction processes play a dominant role in the sedimentation of contaminants and the movement of bottom sediments. These explain the occurrence of instability in the data listed in Tables 3-6. Overall, according to Table 4, the concentrations 
of heavy metals in the water have decreased in recent years, but the concentrations of oil hydrocarbons have increased slightly.

The model was used for the Yenisei River at a distance from the Angara junction to the Kara Sea. The modeling results are shown in Table 6. The sedimentation and selfdecomposition processes cause the chemical concentration to decrease slowly as Yenisei water moves toward its estuary.

It should be noted that the accuracy of the spectral optical systems used in this study was evaluated by Krapivin et al. [22] (see Figure 9.22 in [22]), where it was shown that the accuracy of the evaluation of the contaminant concentration did not exceed $2.7 \%$ for concentrations below $10 \%$. The accuracy of optical decision-making systems changed by up to $5.6 \%$ when the aqueous solution of chemical elements was increased by up to $12.7 \%$.

This paper demonstrates the possibility of spectral optical monitoring in the evaluation of water quality for the Angara/Yenisei River system taking into account hydrological, hydrochemical, and anthropogenic processes. Overall, this paper covers the results of the 2019 hydrochemical expedition study on water quality in the Angara/Yenisei River system, considering the location of existing man-made objects located along the Angara Cascade. Knowledge of the movement of pollution and its concentration at different distances from Lake Baikal allows the assessment of the concentration of contaminants in Lake Baikal and the Kara Sea. Monitoring of water quality from the Angara source provides important data for assessing the current anthropogenic impacts on Lake Baikal. According to the data in Tables 3 and 4, the water quality at site 1 can be considered to correspond to chemical requirements for drinking water quality, which is in line with the conclusion of Suslova and Grebenshchikova [50] based on field measurements in September, 2019.

The use of spectral optical devices for the analysis of Angara water quality allows the functional distinction of the hydrochemical characteristics and the formation of their long-term indicators to control the instability characteristics in their distribution along the Angara Cascade [28]. During the 2019 mission, limited series of measurements were performed at different times of the day, and it was found that the concentration of heavy metals in the water during the day could change by $\pm 2.8 \%$ in reservoirs, regardless of the distance from the Lake Baikal. This result is mainly explained by the irregular outflow of domestic and industrial wastewater in Angara and proposes the synthesis of such a monitoring system, which will use tools and means of information modeling, providing a complex examination of the possible natural and man-made effects on the water quality of the Angara River [22,49].

The problem of functional water quality control in the Angara/Yenisei River system can be simplified by using AYRSSM, taking into account its 3D bed model [50,51]. Digitization of bed relief is possible on the basis of pilot maps. The combination of such models and in situ measurements in individual areas can optimize a process for assessing water quality. According to Krapivin et al. [22], the hybrid geoinformation system can be set up on the basis of information-modeling instrumental technology with the decision-making function to minimize economic factors for progress in assessing the anthropogenic impact on water quality in Lake Baikal, the Angara/Yenisei River system, and the Kara Sea. Moreover, the US-8 spectrophotometer can be mounted on a fixed platform and could provide hydrochemical characteristics at a frequency of several seconds [45].

In situ measurements at 14 selected sites have shown the existence of spatial and temporal variability of the concentrations of chemical elements. Water samples collected in the Irkutsk reservoir in July and August at the same site show that $\mathrm{HCO}_{3}^{-}$and $\mathrm{SO}_{4}^{2-}$ concentrations are $66.51 \pm 1.3 \mathrm{mg} / \mathrm{L}$ and $4.53 \pm 0.47 \mathrm{mg} / \mathrm{L}$, respectively. Computer experiments show that the entry of heavy metals into the Kara Sea from AYRS has a constant value with a depression of $\pm 26 \%$. The impact of the AYRS ecosystem on the heavy metal conversion process does not exceed $2.8 \%$. Heavy metals concentrations in samples taken up the Angara River upstream of the Angara-Yenisei junction are estimated to vary $\pm 1.4 \mathrm{mg} / \mathrm{L}$. Table 5 shows that comparative concentrations of heavy metals and oil 
hydrocarbons in 1995 and 2019 are decreasing and increasing on average 9.7\% and 5.6\%, respectively.

\section{Conclusions}

The results presented in this paper illustrate the features of the combined use of optical spectral instruments for in situ measurements and water sampling analysis to assess the water quality of such a large-scale water system as the Angara-Yenisei River. An advantage of the method developed in this study is the ability to form a database of spectral images of AYRS elements recorded during the year, which allows the estimation of trends in changing AYRS water quality. Comparing spectral images that are made at the same times of different years can help us decide on possible in-situ measurements.

Finally, according to this study and many literature data, the main difficulty in assessing water quality in the Angara/Yenisei River system is the significant variations in hydrochemical characteristics, both during the year and during the day, explained by the irregular water flow and its structure of the bottom relief. The special feature of the AYRS function is determined by the Siberian climate, when the lowest temperatures from October to March are below zero and the AYRS drainage area $\left(3.479 \times 10^{6} \mathrm{~km}^{2}\right)$ is covered by snow that accumulates air pollutants. It should be noted that this should be taken into account when developing AYRSSM. Therefore, the composition of the information modeling system, based on the suitable hydrochemical model and the fixed position of the US- 8 at selected sites, can optimize the solution of the operational control problem and detect dangerous water quality disturbances in the AYRS.

In general, the water quality of the Angara River depends on the feeders from the drainage basin, with an area of $1.039 \times 10^{6} \mathrm{~km}^{2}$. In particular, the AYRS model takes into account this situation of what is possible with the use of remote sensing tools to assess the structure of land cover and soil moisture content. Remote sensing tools have been developed to diagnose water surface and vegetation and are widely used to solve many tasks [6]. Effective diagnosis of vegetation and soil cover is made using microwave instrumental tools based on wavelengths of centimeters [6,52]. Microwave remote sensing tools help to collect data on the spottiness of oil products on the water surface. The detection of pollutant spills can be performed simultaneously with optical and microwave instruments, which improves the precision of AYRSSM input data. The future modernization of the AYRSSM can be achieved with additional blocks, some of which are intended to parameterize the functional dependencies of hydrochemical processes on nonlinear climatic parameters and socio-economic decisions [49,53-55].

The results of this study show the adaptability of the developed information-modeling instrumental technology to monitoring the water quality of every river system, which can improve and increase the productivity of monitoring systems dedicated to water quality. The actual application of AYRSSM to control the water quality of other river systems requires a review of big data clouds, the spatial pixel structure, and the vegetation coverage. The fixed position of the US-8 optical spectral sensor at sites for the formation of spectral images of local water sampling provides an automatic monitoring regime. The implementation of this monitoring regime is the subject of the relevant scientific project.

Author Contributions: C.A.V. and V.F.K. conceived the study design, developed the models, and drafted the manuscript; F.A.M. and Y.X. were involved in data acquisition and analysis and worked on aspects of the experiment. All authors have read and agreed to the published version of the manuscript.

Funding: This work was partially supported by the Russian Foundation for Basic Research, Project No. 19-07-00443-a.

Institutional Review Board Statement: Not applicable.

Informed Consent Statement: Informed consent was obtained from all subjects involved in the study.

Data Availability Statement: Not applicable. 
Conflicts of Interest: The authors declare no conflict of interest.

\section{References}

1. Polyak, L. Siberian River Run-off in the Kara Sea: Characterisation, quantification, variability and environmental significance. Eos 2004, 85, 203-204. [CrossRef]

2. Holmes, R.M.; Peterson, B.J.; Zulidov, V.V.; Gordeev, V. Nutrient chemistry of the Ob' and Yenisey Rivers, Siberia: Results from June 2000 Expedition and evaluation of long-term data sets. Mar. Chem. 2001, 75, 219-227. [CrossRef]

3. Herrault, P.-A.; Gandois, L.; Gascoin, S.; Teisserenc, R. Using high spatio-temporal optical remote sensing to monitor dissolved organic carbon in the arctic River Yenisei. Remote Sens. 2016, 8, 803. [CrossRef]

4. Obolkin, V.; Khodzher, T.; Sorokovikova, L.; Netsvetaeva, O.; Golobokova, L. Effect of long-range transport of sulphur and nitrogen oxides from large coal power plants on acidification of river waters in the Baikal region, East Siberia. Int. J. Environ. Stud. 2016, 73, 452-461. [CrossRef]

5. Makkaveev, P.N.; Polukhin, A.A.; Nalbandov, Y.R.; Khlebopashev, P.V. Dynamics of nutrients in the Yenisei gulf during the open water period. J. Arct. Ecol. Econ. 2019, 4, 69-82. (In Russian) [CrossRef]

6. Varotsos, C.A.; Krapivin, V.F. Microwave Remote Sensing Tools in Environmental Science; Springer: Cham, Switzerland, 2020 ; p. 457.

7. Cracknell, A.P.; Varotsos, C.A. Editorial and cover: Fifty years after the first artificial satellite: From Sputnik 1 to Envisat. Int. J. Remote Sens. 2007, 28, 2071-2072. [CrossRef]

8. Cracknell, A.P.; Varotsos, C.A. New aspects of global climate-dynamics research and remote sensing. Int. J. Remote Sens. 2011, 32, 579-600. [CrossRef]

9. Varotsos, C.A.; Krapivin, V.F. Pollution of Arctic waters has reached a critical point: An innovative approach to this problem. Water Air Soil Pollut. 2018, 229, 343. [CrossRef]

10. Kondratyev, K.Y.; Krapivin, V.F.; Phillips, G.W. Global Environmental Change; Springer: Berlin/Heidelberg, Germany, $2002 ;$ p. 316.

11. Dementiev, D.D.; Bolsunovsky, A.Y.; Borisov, R.V.; Trofimova, E. Concentrations of heavy metals in bottom sediments of the Yenisei River near Krasnoyarsk. Bull. Tomsk Politech. Univ. 2015, 326, 91-98.

12. Karnaukhova, G.A. Water quality and protection: Environmental aspects hydrochemistry of the Angara and reservoirs of the Angara Cascade. Water Resour. 2008, 35, 71-79. [CrossRef]

13. Alieva, V.I.; Pastukhov, M.V. Hydrochemical characteristic of the Angara river in the influence area of the Usolie industrial center. Geogr. Nat. Resour. 2012, 1, 68-73.

14. Khodzher, T.V.; Domysheva, V.M.; Sorokovikova, L.M.; Tomberg, I.V.; Sakirko, M.V. Hydrochemical studies in Lake Baikal: History and nowadays. Limnol. Freshw. Biol. 2018, 1, 2-9. [CrossRef]

15. Bychkov, I.V.; Gagarinova, O.V.; Orlova, I.I.; Bogdanov, V.N. Water protection zoning as an instrument of preservation for Lake Baikal. Water 2018, 10, 1474. [CrossRef]

16. Savichev, O.G.; Matveenko, I.A. Evaluation of chemical composition changes of surface water in Boguchan Reservoir (Siberia, Russia). Hydrol. Sci. J. 2013, 58, 706-715. [CrossRef]

17. Sorokovikova, L.M. Transformation of main ions and water mineralization of the Yenisey River under flow regulation. Water Resour. 1993, 20, 277-282.

18. Kuzmin, M.I.; Tarasova, E.; Mamontova, E.A.; Mamontov, A. Seasonal and interannual variations of water chemistry in the headwater streams of the Angara River (Baikal) from 1950 to 2010. Geochem. Int. 2014, 52, 523-532. [CrossRef]

19. Tarasova, E.; Mamontova, E.E. Features of seasonal and inter-annual variability of chemical composition of Angara River origin. Geokhimia 2014, 7, 579-589. (In Russian)

20. Krapivin, V.F.; Phillips, G.W. Application of a global model to the study of Arctic basin pollution: Radionuclides, heavy metals and oil carbohydrates. Environ. Model. Softw. 2001, 16,1-17. [CrossRef]

21. Krapivin, V.F.; Cherepenin, V.A.; Phillips, G.W.; August, R.A.; Pautkin, A.Y.; Harper, M.J.; Tsang, F.Y. An application of modeling technology to the study of radionuclear pollutants and heavy metals dynamics in the Angara-Yenisey river system. Ecol. Model. 1998, 111, 121-134. [CrossRef]

22. Krapivin, V.F.; Varotsos, C.A.; Soldatov, V.Y. New Ecoinformatics Tools in Environmental Science: Applications and Decision-Making; Springer: London, UK, 2015; p. 903.

23. Andreeva, E.N. The Russian Arctic coastal zone management problems: Past lessons and new realities. Ocean Coast. Manag. 1998, 41, 237-256. [CrossRef]

24. Flint, M.V. (Ed.) Ecosystem of Kara Sea: New data of expedition investigations. In Proceedings of the Scientific Conference, Oceanology Institute, Moscow, Russia, 27-29 May 2015; p. 320.

25. Savenko, A.; Pokrovsky, O.; Strelerskaya, I. Distribution of Dissolved Chemical Elements in the Yenisei River Estuary and Adjacent Water Area of the Kara Sea; Russian State Hydrometeorological University: Saint-Petersburg, Russia, 2016; p. 210.

26. Kondratyev, K.Y.; Krapivin, V.F.; Phillips, G.W. High Latitude Environmental Pollution Problems; Nansen International Environmental and Remote Sensing Center: Saint-Petersburg, Russia, 2002; p. 279.

27. Vyruchalkina, T.Y. Lake Baikal and the Angara River before and after the construction of reservoirs. Water Resour. 2004, 31, 483-489. [CrossRef]

28. Suslova, M.Y.; Grebenshchikova, V.I. Water quality monitoring of the Angara River source. Limnol. Freshw. Biol. 2020, 4, 1040-1041. [CrossRef] 
29. Dementiev, D.D.; Bolsunovsky, A.Y.; Borisov, R.V.; Alexandrova, Y.V. Concentrations of metals in water of the Yenisei River between Krasnoyarsk and the Angara River outfall in 2010-Bulletin of the Tomsk Polytechnic University. Geo Assets Eng. 2017, $328,54-63$.

30. Karnaukhova, G.A. Sedimentation system of the Angara River after regulation of its flow. Doclady Earth Sci. 2007, 413, 351-353. [CrossRef]

31. Pastukhov, M.V.; Poletaeva, V.I.; Tirskikh, E.N. Long-term dynamics of mercury pollution of the Bratsk reservoir bottom sediments, Baikal region, Russia. IOP Conf. Ser. Earth Environ. Sci. 2019, 321, 1-6. [CrossRef]

32. Karnaukhova, G.A. Lithological-Geochemical differentiation of bottom deposits in the Angara Cascade reservoirs. Geochem. Int. 2007, 45, 390-398. [CrossRef]

33. Yushkov, N.N.; Erofeeva, M.R.; Sinegibskaya, A.D. Influence of the economic entities operating on the territory of Bratsk on the state of environmental components. Syst. Methods Technol. 2015, 27, 128-138. (In Russian)

34. Timoshkin, O.A.; Moore, M.V.; Kulikova, N.N.; Tomberg, I.V.; Malnik, V.V.; Shimaraev, M.N.; Troitskaya, E.S.; Shirokaya, A.A.; Sinyukovich, V.N.; Zaitseva, E.P.; et al. Groundwater contamination by sewage causes benthic algal outbreaks in the littoral zone of Lake Baikal (East Siberia). J. Great Lakes Res. 2018, 44, 230-244. [CrossRef]

35. Nemirovskaya, I.A. Variability of concentration and composition of hydrocarbons in frontal zones of the Kara Sea. Oceanology 2015, 55, 497-507. [CrossRef]

36. Kohler, H.; Meon, B.; Gordeev, V.V.; Spitzy, A.; Amon, R.M.W. Dissolved Organic Matter (DOM) in the estuaries of Ob and Yenisei and the adjacent Kara Sea, Russia. In Siberian River Run-off in the Kara Sea: Characterisation, Quantification; Stein, R., Fahl, K., Futterer, D.K., Galimov, E.M., Stepanets, O.V., Eds.; Elsevier Science: Amsterdam, The Netherlands, 2003; pp. 281-308.

37. Karnaukhova, G.A. Belt zoning of sedimentation the Angara Cascade reservoirs. Geochem. Int. 2011, 49, 605-617. [CrossRef]

38. Jagus, A.; Khak, V.; Rzetala, M.A.; Rzetala, M. Accumulation of heavy metals in the bottom sediments of the Irkutsk Reservoir. Int. J. Environ. Health 2013, 6, 350-362. [CrossRef]

39. Mazaeva, O.; Khak, V.A.; Kozhyreva, E.A. Monitoring of local coastal geosystems of the Bratsk Reservoir. Geomorphology 2014, 1, 75-80. (In Russian) [CrossRef]

40. Varotsos, C.A.; Krapivin, V.F.; Mkrtchyan, F.A.; Gevorkyan, S.A.; Tengfei, C. A novel approach to monitoring the quality of lakes water by optical and modeling tools: Lake Sevan as a case study. Water Air Soil Pollut. 2020, 231, 1-7. [CrossRef]

41. Krapivin, V.F.; Mkrtchyan, F.A.; Potapov, I.I.; Soldatov, V.Y. Information-modeling technology for the Nuoc Ngot Lagoon diagnostics on the Vietnam coast. J. Sci. Technol. Binh Duong Univ. 2016, 9, 38-48.

42. Krapivin, V.F.; Varotsos, C.A.; Nghia, B.Q. A modeling system for monitoring water quality in lagoons. Water Air Soil Pollut. 2017, 228, 1-12. [CrossRef]

43. Vakulovsky, S.M.; Tertyshnik, E.G.; Kabanov, A.I. Radionuclide transport in the Yenisei River. At. Energy 2008, 105, 285-291. [CrossRef]

44. Phillips, G.W.; August, R.A.; Cherepenin, V.A.; Harper, M.J.; King, S.E.; Krapivin, V.F.; Pautkin, A.Y.; Tsang, F.Y. Radionuclear pollutants in the Angara and Yenisey rivers of Siberia. Radioprot. Colloq. 1997, 32, 299-304.

45. Varotsos, C.A.; Krapivin, V.F.; Mkrtchyan, F.A. New optical tools for water quality diagnostics. Water Air Soil Pollut. 2019, 230, 1-12. [CrossRef]

46. Bolsunovskii, A.Y.; Degermendzhi, A.G.; Zhizhaev, A.M.; Rubailo, A.L.; Saprykin, A.I. First data on the uranium content in water of the Yenisei River Basin in the area affected by the operation of Rosatom plants. Doclady Earth Sci. 2011, 439, 1010-1015. [CrossRef]

47. FLR. The Federal Law of Russia No. 94-FZ Dated 01.05.1999 "Concerning the Protection of Lake Baikal" (with Amendments as of 28 June 2014). Available online: http:/ / pravo.gov.ru/proxy/ips/?docbody=\&nd=102059482 (accessed on 8 August 2018).

48. Boulion, V.V. Phosphorus budget of Lake Baikal and the Angara Cascade water reservoirs: Modeling, reconstruction, and prognosis. Doklady Biol. Sci. 2018, 480, 90-92. [CrossRef]

49. Krapivin, V.F.; Varotsos, C.A. Biogeochemical Cycles in Globalization and Sustainable Development; Springer/Praxis: Chichester, UK, $2008 ;$ p. 562.

50. Babicheva, V.A.; Rzetala, M.A. The main types of banks of Angara water reservoirs: Overview of the problem. In Proceedings of the 13th International Multidisciplinary Scientific Geoconference, Bulgaria, SGEM 2013, Albena, Bulgaria, 16-22 June 2013; Volume I, pp. 195-202.

51. Bychkov, I.; Gachenko, A.; Rugnikov, G.; Hmelnov, A. 3-D modeling of Angara Riverbed. In Proceedings of the MIT-16: Mathematical and Information Technologies, Vrnjacka Banja, Serbia, 28-31 August 2016; pp. 26-32.

52. Krapivin, V.F.; Nitu, C.; Varotsos, C.A. Microwave Remote Sensing Tools and Ecoinformatics; Matrix Rom: Bucharest, Romania, 2019; p. 332.

53. Efstathiou, M.N.; Varotsos, C.A. On the altitude dependence of the temperature scaling behaviour at the global troposphere. International J. Remote Sens. 2010, 31, 343-349. [CrossRef]

54. Varotsos, C.A.; Efstathiou, M.N.; Cracknell, A.P. On the scaling effect in global surface air temperature anomalies. Atmos. Chem. Phys. 2013, 13, 5243-5253. [CrossRef]

55. Efstathiou, M.N.; Varotsos, C.A. Intrinsic properties of Sahel precipitation anomalies and rainfall. Theor. Appl. Climatol. 2012, 109, 627-633. [CrossRef] 